\title{
PENGEMBANGAN LKPD MENULIS TEKS NARASI BERBASIS KEARIFAN LOKAL MASYARAKAT KOMERING DI SMP
}

\author{
Shakti Abdillah Pratama $^{1 *}$, Herni Fitriani ${ }^{2}$, Fisnia Pratami ${ }^{3}$ \\ Program Studi Pendidikan Bahasa dan Sastra Indonesia \\ STKIP Nurul Huda OKU Timur \\ Shakti@stkipnurulhuda.ac.id \\ hernifitrani@stkipnurulhuda.ac.id \\ fisniapratami@stkipnurulhuda.ac.id
}

\begin{abstract}
Abstrak
Pengembangan bahan ajar perlu dilaksanakan untuk membantu pembelajaran berlangsung secara efektif. Masalah dalam artikel ini yaitu bagaimanakah proses mengembangkan lembar kegiatan peserta didik menulis teks narasi berbasis kearifan lokal masyarakat Komering dan kelayakan sebagai bahan ajar. Tujuan dalam penelitian ini adalah untuk menghasilkan bahan ajar dan mendeskripsikan kelayakan Lembar Kegiatan Peserta Didik Menulis Teks Narasi Berbasis Kearifan Lokal Masyarakat Komering. Metode penelitian pengembangan yang dipakai adalah metode menurut Borg dan Gall. Pengembangan ini menyederhanakan tujuh dari sepuluh langkah dalam prosedur pengembangan sehingga terbentuk produk LKPD Menulis Teks Narasi Berbasis Kearifan Lokal Masyarakat Komering. Penelitian dilakukan dengan tahap observasi, wawancara, penyebaran angket di SMPN 1 Martapura pada tahun ajaran 2021/2022. Produk diuji oleh tiga pakar yang relevan yaitu ahli bidang materi, ahli bidang media, dan ahli praktisi, Selanjutnya, produk diujicobakan kepada peserta didik kelas VII SMP. Hasil penilaian dari tiga validator yaitu, ahli materi mendapat persentase penilaian $95 \%$ kategori sangat layak, ahli media mendapat persentase $85,4 \%$ kategori sangat layak, ahli praktisi persentase $86,4 \%$ kategori sangat layak.
\end{abstract}

Kata Kunci: bahan ajar, teks narasi, dan kearifan lokal Komering.

\section{PENDAHULUAN}

Bahan ajar merupakan sekumpulan materi yang tersusun sistematis, tertulis maupun tidak tertulis sehingga muncul suasana yang mendorong peserta didik dalam belajar (Daryanto dan Dwicahyono, 2014: 171). Bahan ajar merupakan alat berupa teks yang dipakai pendidik dalam pembelajaran. Bahan ajar memuat sekumpulan materi pembelajaran yang tersusun sistematis dan disusun secara tertulis maupun tidak tertulis. Bahan ajar disusun sesuai kurikulum yang berlaku, karakter peserta didik, dan untuk membantu menyelesaikan permasalahan dalam belajar. Pengadaan bahan pembelajaran harus selaras dengan hal yang diperlukan dalam kurikulum dengan menyelaraskan kebutuhan siswa, yakni bahan pembelajaran yang cocok dengan karakter dan kehidupan sosial peserta didik. Bahan pelajaran dikelompokkan ke dalam beberapa wujud yakni salah satunya bahan pelajaran cetak berupa lembar kegiatan peserta didik.

Lembar kegiatan peserta didik merupakan sekumpulan aktivitas yang berkaitan dengan pembelajaran dan mesti diselesaikan oleh siswa. Lembar kegiatan memuat tuntunan dalam belajar, kegiatan untuk memecahkan masalah belajar yang tertulis dalam lembar kegiatan sesuai kompetensi yang hendak diraih (Majid, 2013: 176). Lembar kegiatan siswa digunakan untuk membantu peserta didik dalam belajar sehingga mempermudah pendidik dalam kegiatan belajar mengajar di sekolah. Lembar kegiatan peserta didik adalah bahan pelajaran tertulis berupa kumpulan kertas yang berisi materi, ikhtisar, dan arahan dalam pembelajaran yang harus diselesaikan oleh siswa, sesuai petunjuk pada kompetensi dasar yang akan diraih (Prastowo, 2011: 204).

Sekarang ini, bahan pembelajaran berupa lembar kegiatan peserta didik belum banyak digunakan dan dikembangkan oleh pendidik di sekolah seperti di tingkat SMP. Pada kenyataannya, pendidik bertugas untuk memotivasi, mengarahkan, dan memfasilitasi siswa untuk mencapai tujuan 
PENGEMBANGAN LKPD MENULIS TEKS NARASI BERBASIS .... $\mid 45$ dalam belajar. Dalam proses belajar di sekolah, siswa berkesempatan mengembangkan potensi yang dimilikinya, seperti potensi sikap, pengetahuan, dan keterampilan. Untuk mengembangkan potensi dalam diri peserta didik tersebut diperlukan bahan ajar yang sesuai.

Pembelajaran Bahasa Indonesia di SMP lebih menekankan pembelajaran berbasis teks. Melalui pembelajaran berbasis teks peserta didik diharapkan menguasai hal-hal yang berkaitan dengan keterampilan berbahasa, seperti menulis, membaca, menyimak, dan berbicara. Teks dalam Kurikulum 2013 yang dipelajari pada mata pelajaran Bahasa Indonesia di SMP kelas VII yakni teks deskripsi, teks narasi (cerita fantasi), teks prosedur, teks hasil observasi, dan teks fabel. Salah satu bahan pelajaran yang masih jarang dipakai pendidik di sekolah adalah bahan ajar menulis teks narasi. Dalam pembelajaran, pendidik masih sering terpaku dengan satu bahan ajar yakni buku teks Bahasa Indonesia Kurikulum 2013 edisi revisi. Berdasarkan hasil observasi, di SMPN 1 Martapura Kabupaten OKU Timur belum menggunakan LKPD yang memuat tema kearifan lokal sebagai penunjang buku ajar. Hal tersebut membuat peserta didik kurang memperoleh wawasan yang luas. Ditambah lagi, di era pendemi COVID19, peserta didik cenderung kurang memperhatikan pembelajaran dan bergantung pada gawai dalam menyelesaikan tugas. Oleh sebab itu, LKPD berbasis kearifan lokal perlu dikembangkan dan digunakan dalam pembelajaran.

Teks narasi berisi tentang kisah berdasarkan urutan waktu tertentu sehingga tergambar jelas oleh pembaca. Menurut Keraf (2007: 136) teks narasi merupakan teks yang berbentuk cerita yang menyoroti perbuatan yang dihubungkan dengan suatu peristiwa yang terjadi dalam satu waktu. Narasi disebut juga sebagai suatu bentuk cerita yang berusaha menjelaskan kepada khalayak mengenai satu kejadian yang sudah terjadi. Teks narasi dibangun melalui beberapa struktur teks. Mahsun (2014: 27) menguraikan bahwa unsur teks narasi adalah judul, pengenalan/orientasi, masalah/komplikasi, dan pemecahan masalah.

Pembelajaran menulis teks cerita fantasi (teks narasi) diajarkan di tingkat sekolah menengah pertama kelas VII sesuai KD 3.4 Menelaah struktur dan kebahasaan teks narasi (cerita fantasi) yang dibaca dan didengar dan 4.4 Menyajikan gagasan kreatif dalam bentuk cerita fantasi secara lisan dan tulis dengan memperhatikan struktur dan penggunaan bahasa. Berdasarkan permasalahan itu penulis tertarik untuk melakukan pengembangan LKPD menulis teks narasi. Pengembangan lembar kegiatan peserta didik menulis teks narasi akan dikaitkan dengan kearifan lokal yang ada di masyarakat Komering. Melalui LKPD ini peserta didik dapat memperoleh wawasan mengenai kearifan lokal masyarakat Komering.

Kearifan lokal merupakan suatu runtutan peristiwa dan produk budaya manusia yang digunakan untuk mempertahankan hidup. Kearifan lokal dapat dijadikan sebagai fondasi dalam membentuk karakter luhur. Karakter luhur adalah watak bangsa yang selalu bertindak dengan penuh kesadaran, masa lalu diri, dan pengendalian diri (Wagiran, Jurnal Pendidikan Karakter, Tahun II, Nomor 3, Oktober 2012, diakses 23 Mei 2021, 12:53 WIB). Penambahkan tema kearifan lokal agar peserta didik memiliki pengetahuan tentang budaya lokal yang ada di masyarakat sekitar. Melalui nilai-nilai dalam kearifan lokal peserta didik juga dapat mengembangkan nilai-nilai karakter dalam kehidupannya.

Pengembangan bahan pelajaran berupa lembar kegiatan peserta didik menulis teks narasi pernah dikembangkan oleh Ana Ayu Ningtiyas tahun 2019. Judul pengembangan tersebut yaitu Pengembangan LKPD Menulis Teks Narasi Berbasis Kearifan Lokal Masyarakat Lampung untuk Siswa Kelas VII SMP. Pengembangan tersebut menghasilkan LKPD berbasis kearifan lokal masyarakat Lampung yang sangat layak digunakan oleh peserta didik pada tingkat SMP. Perbedaan dengan pengembangan ini terletak pada pengguanan jenis teks narasi yang berkaitan dengan kearifan lokal masyarakat Komering. Melalui kearifan lokal masyarakat Komering diharapkan peserta didik mampu mengenal kearifan lokal (cerita rakyat) yang ada di masyarakat Komering.

Pengembangan bahan pelajaran menulis teks narasi berbasis kearifan lokal masyarakat Komering akan dibuat dalam bentuk lembar kegiatan peserta didik sehingga dapat digunakan siswa dalam pembelajaran dengan mandiri atau dengan arahan dari pendidik. Pengembangan bahan ajar ini diharapkan bisa menambah minat peserta didik dalam mempelajari materi tentang menulis teks narasi 


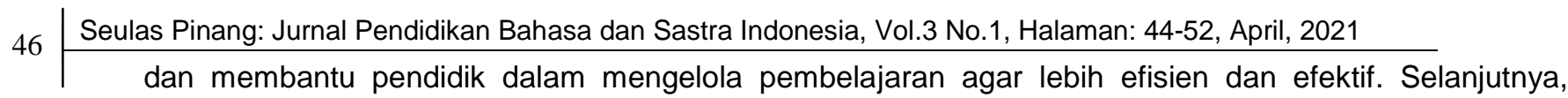
pendidik juga dapat menggunakan lembar kegiatan peserta didik sebagai buku pendukung dari buku teks Bahasa Indonesia kelas VII Kurikulum 2013 edisi Revisi.

\section{METODE PENELITIAN}

\section{Model Pengembangan}

Penelitian pengembangan Lembar Kegiatan Peserta Didik Menulis Teks Narasi Berbasis Kearifan Lokal Masyarakat Komering dilakukan menggunakan metode penelitian pengembangan atau Research and Development $(R \& D)$. Penelitian ini termasuk dalam penelitian pengembangan sebab menghasilkan produk atau menyempurnakan produk yang sudah ada. Menurut Borg dan Gall dalam Sugiyono (2016: 28), educational research and development is aprocess used to develop and validate educational product atau dapat diartikan bahwa penelitian pengembangan pendidikan merupakan rangkaian penelitian yang dipakai dalam mengembangkan dan menguji produk pendidikan.

\section{Tempat Penelitian}

Penelitian ini dilakukan di SMPN 1 Martapura tahun pelajaran 2021/2022. Penelitian dilaksanakan pada hari Rabu, 10 Februari 2021 berdasarkan pertimbangan efisiensi waktu, tenaga, dan biaya.

\section{Spesifikasi Produk Pengembangan}

Bahan pelajaran yang dikembangkan dalam penelitian pengembangan ini berupa LKPD Menulis Teks Narasi Berbasis Kearifan Lokal Masyarakat Komering untuk Siswa Kelas VII SMP dengan spesifikasi sebagai berikut.

1. Lembar kegiatan peserta didik merupakan lembar kegiatan mata pelajaran Bahasa Indonesia yang mesti diselesaikan oleh siswa tingkat Sekolah Menengah Pertama kelas VII.

2. Lembar kegiatan memuat ketentuan dan tahap-tahap dalam menyelesaikan latihan sesuai dengan KD 3.4 Menelaah struktur dan kebahasaan teks narasi (cerita fantasi) yang dibaca dan didengar dan 4.4 Menyajikan gagasan kreatif dalam bentuk cerita fantasi secara lisan dan tulisan dengan memperhatikan struktur teks dan penggunaan Bahasa Indonesia.

3. Lembar kegiatan peserta didik ini digunakan untuk pelajaran Bahasa Indonesia tingkat SMP kelas VII dan digunakan sebagai buku pendukung buku Teks Bahasa Indonesia Kurikulum 2013 Revisi 2016.

4. Lembar kegiatan ini dirancang dengan urutan halaman sampul LKPD, arahan bimbingan belajar bagi guru dan peserta didik, Kompetensi Inti dan Kompetensi Dasar, materi pendukung, kegiatan yang harus dikerjakan peserta didik, daftar istilah (glosarium), dan daftar pustaka.

\section{Langkah Penelitian Pengembangan}

Penulis menyederhanakan tahapan dalam penelitian dan pengembangan Borg dan Gall yang dilakukan dengan tujuh langkah sampai terbentuk lembar kegiatan yang layak untuk diujicobakan di sekolah. Penelitian pengembangan ini dimulai dengan studi pendahuluan yang merupakan bagian research (R) pertama dalam RDR. Studi pendahuluan dilakukan untuk mendapat informasi awal mengenai analisis hal yang dibutuhkan dan keadaan sekolah yang membutuhkan pengembangan bahan ajar. Hasil studi pendahuluan dipakai sebagai dasar dalam pengembangan produk. Desain pengembangan produk merupakan bagian development (D) dalam RDR. Langkah-langkah hasil penyederhanaan pengembangan Borg dan Gall digolongkan menjadi tiga langkah utama yaitu studi pendahuluan, pengembangan produk, dan penilaian produk (Borg and Gall, 2003: 775). 
PENGEMBANGAN LKPD MENULIS TEKS NARASI BERBASIS .... 47

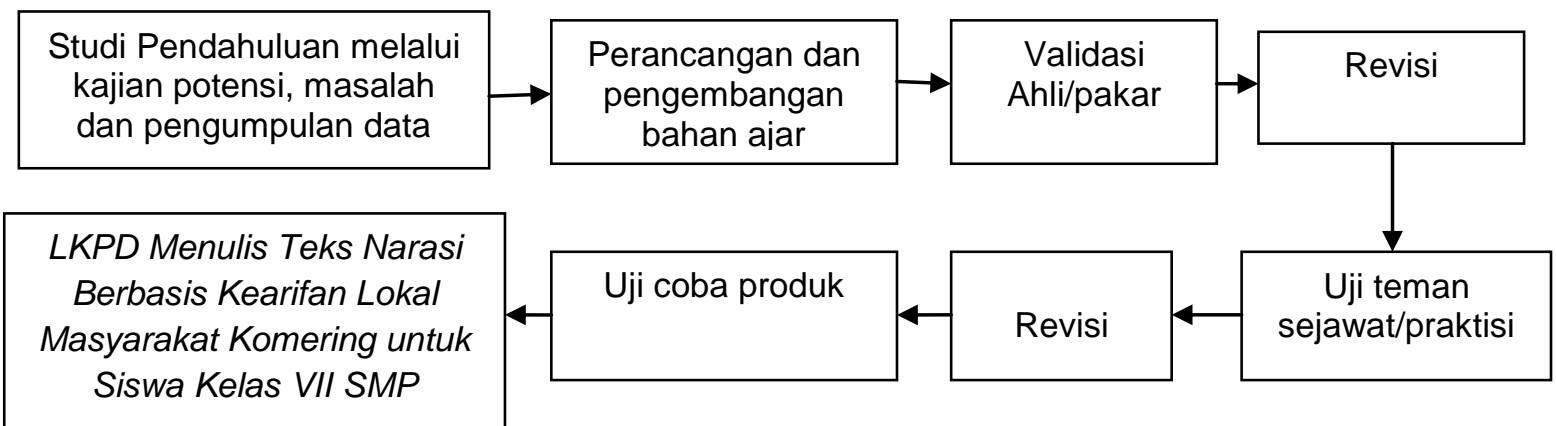

\section{Gambar tahapan pengembangan LKPD}

Tahapan tersebut kemudian diuraikan dalam langkah-langkah yakni sebagai berikut.

(1) Menganalisis permasalahan dan kebutuhan bahan pelajaran di sekolah.

(2) Menghimpun informasi mengenai keperluan bahan pelajaran berupa LKPD menulis teks narasi.

(3)Pembuatan bahan pelajaran dengan mendesain produk dan mengembangkan hingga terbentuk produk awal.

(4) Penilaian produk LKPD dengan uji coba oleh pakar yang relevan yakni pakar media, pakar materi, dan ahli praktisi. Tiga pakar memberikan nilai dalam kuesioner, kemudian hasil nilai yang didapat dikonversi dalam klasifikasi tingkat kelayakan sejalan dengan tabel kelayakan referensi menurut Riduwan dan Sunarto (2009:23).

Tabel 1 Konversi Penilaian Pengembangan LKPD

\begin{tabular}{|l|l|l|}
\hline No. & \multicolumn{1}{|c|}{ Rentang Skor } & \multicolumn{1}{c|}{ Kriteria } \\
\hline 1 & $0 \%-20 \%$ & Tidak Layak \\
\hline 2 & $21 \%-40 \%$ & Kurang Layak \\
\hline 3 & $41 \%-60 \%$ & Cukup Layak \\
\hline 4 & $61 \%-80 \%$ & Layak \\
\hline 5 & $81 \%-100 \%$ & Sangat Layak \\
\hline
\end{tabular}

(5) Perbaikan rancangan lembar kegiatan setelah penilaian.

(6) Pengujian lembar kegiatan pada rekan sejawat dan uji coba kepada siswa.

(7) Perbaikan lembar kegiatan hingga terbentuk produk berupa lembar kegiatan peserta didik yang siap uji efektifitasnya.

\section{HASIL DAN PEMBAHASAN}

Hasil

Hasil penelitian dan pengembangan ini adalah terbentuknya bahan ajar Lembar Kegiatan Peserta Didik Menulis Teks Narasi Berbasis Kearifan Lokal Masyarakat Komering untuk Siswa SMP Kelas VII. Tahapan pengembangan bahan pembelajaran yang penulis gunakan adalah pengembangan bahan ajar yang dikemukakan oleh Sugiyono (2016: 407) yaitu;

(1) analisis permasalahan dan kebutuhan bahan pelajaran di sekolah;

(2) menghimpun informasi yang mendukung;

(3) merancang lembar kegiatan peserta didik;

(4) penilaian rancangan produk lembar kegiatan;

(5) perbaikan rancangan lembar kegiatan;

(6) mengujicobakan LKPD;

(7) perbaikan LKPD hingga terbentuk bahan pelajaran (lembar kegiatan peserta didik). Hasil validasi menunjukkan produk memperoleh penilaian dari tiga pakar dan mendapat penilaian kelayakan 95\% dari pakar materi, pakar media $85,4 \%$, dan ahli praktisi $86,4 \%$ dengan kriteria sangat layak. 


\section{Pembahasan}

\section{A. Proses Pengembangan LKPD Menulis Teks Narasi Berbasis Kearifan Lokal Masyarakat Komering untuk Siswa Kelas VII SMP}

\section{Potensi dan Masalah}

Melalui observasi di SMPN 1 Matapura ditemukan potensi dan masalah yaitu kurangnya minat siswa dalam pelajaran menulis teks narasi. Siswa mengalami kesulitan menuangkan ide dalam menulis teks narasi. Selain itu, pendidik di sekolah tersebut hanya menggunakan satu sumber belajar yaitu buku teks Bahasa Indonesia Kurikulum 2013 revisi 2016 dan belum mengaplikasikan bahan pelajaran pendukung yang memuat kearifan lokal masyarakat Komering. Di era pendemi COVID-19 pembelajaran dilakukan dengan metode pembelajaran jarak jauh sehingga menyebabkan peserta didik bergantung pada gawai. Peserta didik cenderung kurang fokus dalam pembelajaran, termasuk dalam hal mencari jawaban ketika mengerjakan tugas. Peserta didik sering kali menyalin jawaban tugas dari internet. Adanya hal tersebut perlu adanya bahan ajar yang menuntut siswa mandiri dalam menyelesaikan tugas.

\section{Pengumpulan Data}

Selanjutnya, langkah dalam mengumpulkan informasi pendukung yakni, mengkaji kurikulum yang berlaku saat ini dan mencari sumber rujukan yang relevan dengan pengembangan bahan ajar menulis teks narasi berbasis kearifan lokal masyarakat Komering. Kurikulum acuan yang digunakan di sekolah saat ini adalah Kurikulum 2013 revisi 2016. Penulis kmudian menganalisis bagian dalam kurikulum seperti Kompetensi Inti, Kompetensi Dasar, Indikator, dan materi pelajaran yang berkaitan dengan pengembangan lembar kegiatan. Berdasarkan hasil analisis menunjukkan bahwa ada keterkaitan antara bagian yang ada di kurikulum dengan materi pelajaran menulis teks narasi. Adapun, pembeda lembar kegiatan ini dengan buku paket ialah terletak pada contoh teks narasi yang digunakan. Teks narasi yang digunakan berkaitan dengan kearifan lokal berupa cerita rakyat masyarakat Komering.

Langkah selanjutnya yaitu menganalisis beberapa rujukan untuk mengembangkan bahan pelajaran berupa Lembar Kegiatan Peserta Didik Menulis Teks Narasi Berbasis Kearifan Lokal Masyarakat Komering. Referensi tersebut berupa teks narasi yang ceritanya tentang kisah yang memuat unsur kearifan lokal masyarakat Komering, materi yang berkaitan dengan struktur dan teks narasi dalam buku teks pelajaran Bahasa dan Sastra Indonesia Kurikulum 2013 Revisi 2016. Penyesuaian tersebut dilakukan agar lembar kegiatan yang dikembangkan sesuai dengan buku acuan dari Kemendikbud. Setelah mengkaji rujukan yang relevan dengan bahan pelajaran menulis teks narasi, tahap selanjutnya yaitu mengembangkan rancangan awal (mendesain produk) yakni melengkapi bagian-bagian dalam bahan ajar Lembar Kegiatan Peserta Didik Menulis Teks Narasi Berbasis Kearifan Lokal Masyarakat Komering.

\section{Desain Produk}

Perancangan lembar kegiatan peserta didik penulis lakukan dengan cara: (1) penetapan materi pelajaran yang dikembangkan sesuai karakter siswa, penetapan materi pelajaran harus sesuai dengan kondisi peserta didik baik dari segi latar belakang sosial dan budaya, aspek kebahasaan, dan aspek kejiwaan, (2) menjabarkan bagian-bagian materi, penjabaran bagian materi yakni analisis muatan materi pelajaran, Kompetensi Inti, Kompetensi Dasar, indikator, dan materi yang termuat dalam pengembangan buku ajar, (3) perumusan tema LKPD, rumusan judul dikaitkan dengan Kompetensi Dasar yang digunakan (4) desain pengembangan materi pelajaran, dalam mendesain lembar kerja harus menyesuaikan dengan beberapa unsur yaitu kesesuaian dengan kenyataan yang ada, aturan, konsep, dan nilai, (5) langkah menyusun kelengkapan materi diawali dengan penyusunan halaman sampul yaitu halaman judul, daftar isi, kata pengantar, pendahuluan (petunjuk untuk guru dan peserta didik), halaman $\mathrm{KI}$ dan KD yang sesuai dengan lembar kegiatan, isi LKPD beserta soal latihan, glosarium, dan daftar rujukan. 


\section{Validasi Desain}

Setelah perancangan produk dibuat selanjutnya lembar kegiatan dinilai oleh 3 pakar yang relevan. Pakar yang menilai tersebut yaitu, Ibu Indah Sulmayanti, M.Pd. sebagai pakar bidang materi, Ibu Khusnatul Amaliah, M.Kom. sebagai pakar di bidang media dan Ibu Hj. Niar, M.Pd. sebagai ahli praktisi. Pakar materi memberikan penilaian $95 \%$. Ahli media yang mevalidasi produk dengan penilaian $85,4 \%$. Ahli praktisi yang memvalidasi produk memberi penilaian $86,4 \%$. Ketiga nilai tersebut dikategorikan sangat layak diujicobakan di sekolah.

\section{Perbaikan Desain}

Tiga pakar yakni, pakar media, pakar materi, dan ahli praktisi memberikan saran perbaikan. Adapun saran yang diberikan seperti pembenahan penulisan kata agar sesuai dengan kaidah kebahasaan Bahasa Indonesia. Selain itu, pembenahan bagian sampul, yaitu penambahan sumber gambar, ukuran huruf penulisan sumber. Menambahkan sampul bagian belakang.

\section{Pengujian Produk}

Lembar Kegiatan Peserta Didik Menulis Teks Narasi Berbasis Kearifan Lokal Masyarakat Komering untuk Siswa SMP Kelas VII diujicobakan dan dinilai guru Bahasa Indonesia SMPN 1 Martapura Kabupaten OKU Timur. Guru SMPN 1 Martapura memberikan saran peneliti agar memberikan saran untuk memperbaiki penulisan kata dalam kalimat pada halaman 18. Selanjutnya, produk diujikan kepada 30 peserta didik. peserta didik menilai lembar kegiatan setelah lembar kegiatan tersebut diaplikasikan dalam pembelajaran. Peserta didik akan merasa paham dalam penilaian dan pemberian saran karena telah menggunakan lembar kegiatan peserta didik ini. Adapun saran yang diberikan peserta didik memperbaiki cetakan tulisan yang terpotong di halaman 10.

\section{Revisi Produk}

Pada langkah terakhir ini, penulis memperbaiki lembar kegiatan hingga terbentuk bahan pelajaran berupa Lembar Kegiatan Peserta Didik Menulis Teks Narasi Berbasis Kearifan Lokal Masyarakat Komering untuk Siswa Kelas VII SMP. Hasil dari pengembangan bahan pelajaran sesuai dengan hasil masukan pakar materi, pakar media, guru, dan peserta didik yang menjadi penilai dan pemberi saran terhadap penyempurna bahan ajar berupa Lembar Kegiatan Peserta Didik Menulis Teks Narasi Berbasis Kearifan Lokal Masyarakat Komering untuk Siswa Kelas VII SMP.

\section{B. Analisis Kelayakan Produk}

Menurut hasil penilaian produk kepada tiga pakar dan pengujian produk di sekolah dapat diketahui bahan pelajaran berupa Lembar Kegiatan Peserta Didik Menulis Teks Narasi Berbasis Kearifan Lokal Komering untuk Siswa Kelas VII SMP ini layak diaplikasikan dalam pembelajaran mata pelajaran Bahasa Indonesia kelas VII SMP sebagai buku pendukung buku teks. Hal ini diperkuat dengan hasil perhitungan nilai dalam kuesioner kelayakan oleh pakar materi, pakar media, ahli praktisi, guru Bahasa dan Sastra Indonesia, dan peserta didik yang memberi penilaian terhadap produk bahan ajar berupa Lembar Kegiatan Peserta Didik Menulis Teks Narasi Berbasis Kearifan Lokal Komering untuk Siswa Kelas VII SMP. Penilai mengisi kuesioner penilaian tentang kelayakan bahan pelajaran berupa Lembar Kegiatan Peserta Didik Menulis Teks Narasi Berbasis Kearifan Lokal Komering untuk Siswa Kelas VII SMP. Jumlah indikator penilaian guru SMPN 1 Martapura adalah sebanyak empat aspek dengan dua puluh indikator. 

berikut.

Adapun hasil skor persentase yang didapat sesuai penilaian beberapa kriteria yakni sebagai

1. Pakar bidang materi mendapat skor presentase $95 \%$.

Tabel 2 Penilaian Ahli Materi

\begin{tabular}{|c|l|l|l|}
\hline \multirow{2}{*}{ No. Aspek } & \multicolumn{2}{c|}{ Hasil } \\
\cline { 3 - 4 } & & Skor Persentase & Karakteristik \\
\hline 1. & Isi & 97,5 & Sangat Layak \\
\hline 2. & Bahasa & 85,7 & Sangat Layak \\
\hline 3. & Penyajian & 95,8 & Sangat Layak \\
\hline 4. & Kegrafisan & 100 & Sangat Layak \\
\hline Total & & $\mathbf{9 5}$ & Sangat layak \\
\hline
\end{tabular}

2. Pakar media memperoleh skor penilaian sebanyak $85,4 \%$

Tabel 3 Validasi Ahli Media

\begin{tabular}{|c|c|c|c|}
\hline \multirow[t]{2}{*}{ No. } & \multirow[t]{2}{*}{ Aspek } & \multicolumn{2}{|c|}{ Hasil } \\
\hline & & Skor Persentase & Karakteristik \\
\hline 1. & Sajian & 91,6 & Sangat Layak \\
\hline 2. & Kegrafisan & 79,2 & Layak \\
\hline Total & & 85,4 & Sangat layak \\
\hline
\end{tabular}

3. Ahli praktisi memperoleh hasil penilaian $86,4 \%$.

Tabel 4 Validasi Ahli Praktisi

\begin{tabular}{|c|c|c|c|}
\hline \multirow[t]{2}{*}{ No. } & \multirow[t]{2}{*}{ Aspek } & \multicolumn{2}{|c|}{ Hasil } \\
\hline & & Skor Persentase & Karakteristik \\
\hline 1. & Isi & 90 & Sangat Layak \\
\hline 2. & Bahasa & 85 & Sangat Layak \\
\hline 3. & Penyajian & 87,5 & Sangat Layak \\
\hline 4. & Kegrafisan & 83 & Sangat Layak \\
\hline Total & & 86,4 & Sangat layak \\
\hline
\end{tabular}

Nilai persentase di atas kemudian dikonversi dalam kategori tingkat kelayakan sesuai dengan tabel kelayakan Riduwan dan Sunarto (2009:23), maka penilaian persentase dikategorikan sangat layak. Lembar kegiatan peserta didik dikategorikan layak karena sudah memenuhi kriteria kelayakan sesuai kriteria kelayakan isi, kelayakan bahasa, kelayakan sajian, dan kelayakan kegrafisan. Menurut para ahli, lembar kegiatan peserta didik tersbut dapat diujikan di SMP setelah diperbaiki sesuai dengan saran.

4. Penilaian Guru SMPN 1 Martapura memperoleh nilai 70,33\%

Tabel 5 Penilaian Kelayakan LKPD dari Guru Bahasa Indonesia

\begin{tabular}{|r|l|l|l|}
\hline \multirow{2}{*}{ No. } & \multirow{2}{*}{ Aspek } & \multicolumn{2}{|c|}{ Hasil } \\
\cline { 3 - 4 } & \multirow{2}{*}{} & \multicolumn{2}{|c|}{ Guru SMPN 1 Martapura } \\
\cline { 3 - 4 } & & Skor & \multicolumn{1}{c|}{ Kriteria } \\
\hline 1. & Isi & 73,33 & Layak \\
\hline 2. & Bahasa & 75 & Layak \\
\hline 3. & Penyajian & 68 & Layak \\
\hline 4. & Kegrafikan & 65 & Layak \\
\hline Total & 70,33 & Layak \\
\hline
\end{tabular}


5. Peserta didik dari SMPN1 Martapura memberikan penilaian $89,5 \%$

Tabel 6 Penilaian Siswa terhadap Kelayakan Bahan Ajar

\begin{tabular}{|r|l|l|l|}
\hline \multirow{2}{*}{ No. } & \multirow{2}{*}{ Aspek } & \multicolumn{2}{c|}{ Hasil } \\
\cline { 3 - 4 } & \multirow{2}{*}{} & \multicolumn{2}{|c|}{ Siswa SMPN 1 Martapura } \\
\cline { 2 - 4 } & Skor & \multicolumn{1}{c|}{ Kriteria } \\
\hline 1. & Isi & 90 & Sangat layak \\
\hline 2. & Bahasa & 91 & Sangat layak \\
\hline 3. & Penyajian & 86 & Sangat layak \\
\hline 4. & Kegrafikan & 91 & Sangat layak \\
\hline Total & 89,5 & Sangat layak \\
\hline
\end{tabular}

Hasil dari peilaian dari guru Bahasa Indonesia SMPN 1 Martapura mendapat skor persentase 70,33\% dengan kriteria layak digunakan. Hasil kuesioner uji coba bahan ajar Lembar Kegiatan Peserta Didik Menulis Teks Narasi diperoleh juga data tentang kelebihan dan kekurangan mata pelajaran Bahasa Indonesia khususnya materi pembelajaran menulis teks narasi. Adapun kelebihan bahan ajar lembar kegiatan peserta didik ini yaitu lembar kegiatan disusun secara baik, dapat digunakan dalam pembelajaran, dan memuat nilai-nilai kehidupan dalam teks narasi.

Selanjutnya, penilaian kelayakan lembar kegiatan peserta didik dilakukan oleh tiga puluh peserta didik SMPN 1 Martapura. Pengisian kuesioner dilakukan setelah pengaplikasian lembar kegiatan dalam pembelajaran. Adanya hal tersebut diharapkan peserta didik benar-benar memahami dan mencermati lembar kegiatan sehingga peserta didik dapat menilai kuesioner dengan benar. Adapun skor persentase yang diperoleh dalam penilaian yaitu $89,5 \%$ dengan kategori sangat layak. Sesuai uji coba yang telah dilakukan, terlihat kelemahan dan kelebihan dari lembar kegiatan peserta didik ini. Lembar kegiatan peserta didk ini mudah dipahami karena memuat contoh kutipan teks narasi yang sesuai dengan kondisi siswa dan diharpkan dapat menumbuhkan semangat belajar setelah mempelajarinya. Bahan ajar ini dapat menjadikan peserta didik berpikir kritis, kreatif, dan inovatif. Adapun kelemahan lembar kegiatan peserta didik ini yaitu terdapat cetakan tulisan terpotong sehingga harus direvisi kembali.

Berdasarkan penilaian dan saran Lembar kegiatan Peserta Didik Menulis Teks Narasi oleh guru Bahasa dan Sastra Indonesia dan peserta didik di SMPN 1 Martapura kemudian lembar kegiatan diperbaiki sesuai saran seperti menambahkan hal yang kurang dan memperbaiki yang salah. Melalui revisi ini hendaknya guru dan peserta didik kelas VII SMP bisa mengaplikasikan bahan pelajaran berupa Lembar kegiatan Peserta Didik ini dengan baik untuk buku pendukung buku Teks Bahasa Indonesia Kurikulum 2013 Revisi 2016 kelas VII.

\section{PENUTUP}

Bahan ajar berupa Lembar Kegiatan Peserta Didik Menulis Teks Narasi Berbasis Kearifan Lokal Masyarakat Komering untuk Siswa Kelas VII SMP telah berhasil dikembangkan. Pengembangan tersebut dilakukan dengan tujuh tahap pengembangan dengan urutan bagian produk: halaman sampul LKPD, petunjuk pemakaian lembar kegiatan, Kompetensi Inti dan Kompetensi Dasar, daftar isi, materi teks narasi, info pendukung atau glosarium, dan daftar pustaka. Produk diujikan kepada tiga ahli/pakar yaitu ahli media, ahli materi, dan ahli praktisi. Dari hasil penilaian tiga pakar menunjukkan produk layak diujicobakan di sekolah. Setelah validasi ahli, produk diujicobakan di SMPN 1 Martapura. Dalam pengujian produk memperoleh penilaian dari guru dan peserta didik. Penilaian dari pendidik dan peserta didik menunjukkan produk dapat diaplikasikan dalam pelajaran Bahasa Indonesia pada kegiatan menulis teks narasi di kelas VII SMP sebagai buku pendukung buku Teks Bahasa Indonesia Kurikulum 2013 revisi 2016. 


\section{UCAPAN TERIMAKASIH}

Ucapan terima kasih tim peneliti sampaikan kepada STKIP Nurul Huda yang melalui LPPMnya telah membiayai dan memfasilitasi penelitian ini.

\section{DAFTAR PUSTAKA}

Borg dan Gall. 2003. Educational Research an Introduction,Seventh Editions. University of Oregon. United State of America.

Daryanto dan Aris Dwicahyono. 2014. Pengembangan Perangkat Pembelajaran (Silabus, RPP, PHB, Bahan ajar). Yogyakatra: Gava Media.

http://ejurnal.bbg.ac.id/metamorfosa/article/download/265/234 (Diakses pada 11 Desember 2020)

http://jurnal.fkip.unila.ac.id/index.php/BINDO/article/view/10853 (Diakses pada 2 Desember 2020, 09:52 WIB)

Keraf, Gorys.2007. Argumentasi dan Narasi. Jakarta: PT Gramedia Pustaka Utama.

Mahsun. 2014. Teks dalam Pembelajaran Bahasa Indonesia Kurikulm 2013. Jakarta: Raja Grafindo Persada.

Majid, Abdul. 2013. Perencanaan Pembelajaran. Bandung: PT Remaja Rosdakarya.

Ningtiyas, Ana Ayu. 2019. Pengembangan LKPD Menulis Teks Narasi Berbasis Kearifan Lokal Masyarakat Lampung Untuk Siswa Kelas VII SMP. (Tesis). Lampung: Universitas Lampung.

Prastowo, Andi. 2012. Panduan Kreatif Membuat Bahan Ajar Inovatif. Yogyakarta: Diva Press.

R, Himawan Bastari. 2019. Negeri Para Phuyang Hikayat Komering Pitu Phuyang. Jawa Tengah: CV. Intishar Publishing.

Riduwan dan Sunarto. 2009. Pengantar Statistika. Bandung: ALFABETA.

Sugiyono. 2016. Metode Penelitian dan Pengembangan (Research and Development). Bandung: Alfabeta.

Syahputra, Ridwan. 2016. Pengembangan Bahan Ajar Menulis Teks Eksposisi Berbasis Teks Kearifan Lokal di SMA.(Tesis). Medan: Universitas Negeri Medan.

Syani, Abdul. 2013. Menumbuhkan Kembali Nasionalisme Melalui Nilai-nilai Kearifan Lokal. Lampung: http://staff.unila.ac.id/abdulsyani/2013. Diakses tanggal 17 Desember 2020.

Tarigan, Henry Guntur. 1987. Membaca sebagai suatu Keterampilan Berbahasa. Bandung: Angkasa.

Tarigan, Henry Guntur. 2008. Menulis sebagai Suatu Keterampilan Berbahasa. Bandung: Angkasa.

Wagiran. 2012. Pengembangan Karakter Berbasis Kearifan Lokal Hamemayu Hayuning Bawana (Identifikasi Nilai-nilai Karakter Berbasis Budaya). Jurnal Pendidikan Karakter. Tahun II, Nomor 3. 